\title{
Arctic Fox Migrations in Manitoba
}

\author{
ROBERT E. WRIGLEY and DAVID R. M. HATCH ${ }^{1}$
}

\begin{abstract}
A review is provided of the long-range movements and migratory behaviour of the arctic fox in Manitoba. During the period 1919-75, peaks in population tended to occur at three-year intervals, the number of foxes trapped in any particular year varying between 24 and 8,400 . Influxes of foxes into the boreal forest were found to follow decreases in the population of their lemming prey along the west coast of Hudson Bay. One fox was collected in 1974 in the aspen-oak transition zone of southern Manitoba, $840 \mathrm{~km}$ from Hudson Bay and almost $1000 \mathrm{~km}$ south of the barren-ground tundra, evidently after one of the farthest overland movements of the species ever recorded in North America.
\end{abstract}

RÉSUMÉ. Les migrations du renard arctique au Manitoba. On présente un compterendu des mouvements à long terme et du comportement migrateur du renard arctique au Manitoba. Durant la période de $1919-75$, les maxima de peuplement tendaient à revenir à des intervalles de trois ans, le nombre de renards pris au piège dans une année donnée variant entre 24 et 8,400 . On a constaté que l'aftlux de renards dans la forêt boréale suivait les diminutions de population chez leurs proies, les lemmings, en bordure de la côte occidentale de la mer d'Hudson. En 1974, on a trouvé un renard dans la zone de transition de trembles et de chênes, dans le sud du Manitoba, à 840 kilomètres de la mer d'Hudson et à presque 1000 kilomètres au sud des landes de la tundra. Ceci est de toute évidence un des déplacements les plus considérables par voie de terre de cette espèce jamais enregistré en Amérique du Nord.

РЕЗЮМЕ. Миграчии песча в Маяитобе. Проведен обвор передвижений песца на большие расстояния и характера его миграций в Манитобе. В период 19191975 гг. максимумы популяций имели тенденцию повторяться каждые три года, причем число отловленных песдов в любом году менялось от 24 до 8400. Было установлено, что приток песцов в арктические леса происходит в результате снижения популяцин уничтожяемых ими пеструпек вдоль западных берегов Гудзонова залива. В 1974 году в южной Манитобе в зоне перехода от осины к дубу, расположенной в 840 км от Гудзонова валива и почти в 1000 км южнее голой тундры, был пойман песец, который совершил, по всей вероятности, один из длиннейших переходов по суше, когда-либо зарегистрированных в Северной Америке для данного вида.

\section{INTRODUCTION}

In mid-December 1974, a female arctic fox (Alopex lagopus) was shot as it fed on a goose along the frozen shore of East Shoal Lake in southern Manitoba $\left(50^{\circ} 23^{\prime} \mathrm{N}, 97^{\circ} 37^{\prime} \mathrm{W}\right)$, less than $145 \mathrm{~km}$ from the North Dakota border. The animal (Fig. 1) must have travelled a minimum distance of $840 \mathrm{~km}$ from the closest summer range (York Factory on Hudson Bay) and perhaps came from the barren-ground tundra, almost $1,000 \mathrm{~km}$ to the north. This movement is one of the farthest south of the breeding range by an overland route ever recorded in North America. The individual was part of a migration of arctic foxes which swept south into the boreal forest from the coastal tundra of Hudson Bay and

\footnotetext{
1Manitoba Museum of Man and Nature, 190 Rupert Avenue, Winnipeg, Manitoba,
} Canada R3B ON2. 




FIG. 1 Arctic fox and coyote collected at East Shoal Lake, Manitoba.

the barren grounds of the District of Keewatin in the Northwest Territories during the winter of 1974-75.

The importance of arctic fox to the fur trade has led to intensive research on the fluctuations and movements of this furbearer in the U.S.S.R. (Lavrov 1932; Bannikov 1970) and in Greenland (Braestrup 1941). In contrast, studies in North America, particularly of movements, have consisted in the main of isolated observations, except in Ungava (Elton 1942) and Alaska (Chesemore 1968a). In the present paper are described the main features of arctic fox migration, and the fluctuations and movements of the species in Manitoba (through reports by trappers and conservation officers, and from fur-trade records) in relation to abundance of rodents, their main prey.

\section{REVIEW OF ARCTIC FOX MOVEMENTS}

The breeding range of the arctic fox is Holarctic, including barren grounds, coastal tundra, remote islands, and even the alpine tundra of Scandinavia. During a winter migration, foxes move north onto the polar ice, penetrate southward into the forest-tundra transition and boreal forest, or travel in an east-west direction within the tundra or along the coast (Shilyaeva 1967; Bannikov 1970). In certain winters, up to two-thirds of the population may leave the tundra, perhaps the same number penetrating the forest as spreading onto the pack ice, and foodgathering range is thereby increased several times (Bannikov 1970).

In a review of the literature of this species, McEwen (1951) distinguished several types of movements: local (involving general activities over the animal's home range throughout the year), seasonal (correlated with seasonal changes, not involving great numbers of foxes or long distances, which may or may not occur 
annually), migratory (large number of foxes travelling rapidly in a sustained direction, as a result of a decline in the numbers of lemmings), and sporadic (individual appearance at a great distance from normal breeding range, not correlated with any particular environmental factors).

An arctic fox may cover great distances for its small size (it weighs no more than a house cat). Chesemore (1968a) recorded a sighting of a fox on the polar pack ice $640 \mathrm{~km}$ north of the Alaskan coast and the trapping of another at Wainwright, Alaska with a Russian ear tag. An arctic fox, ear-tagged, radiocollared and released on Banks Island, N.W.T. $\left(73^{\circ} 25^{\prime} \mathrm{N}, 121^{\circ} 25^{\prime} \mathrm{W}\right)$ on 10 August 1974 was killed by a vehicle at Prudhoe Bay, Alaska on 20 November 1974 - a straight-line movement westward of $1,000 \mathrm{~km}$ in 102 days (L. S. Underwood, personal communication). Another fox, ear-tagged and radio-collared on Banks Island $\left(74^{\circ} 14^{\prime} \mathrm{N}, 119^{\circ} 55^{\prime} \mathrm{W}\right)$ on 8 August 1974 , was trapped near Repulse Bay, N.W.T. $\left(66^{\circ} 27^{\prime} \mathrm{N}, 84^{\circ} 24^{\prime} \mathrm{W}\right)$ on 15 April 1975 - a straight-line movement eastward of $1,530 \mathrm{~km}$ in 250 days (J. T. Strong, personal communication). Uspenskii (1956) reported a fox reaching the latitude of $88^{\circ} \mathrm{N}, 800 \mathrm{~km}$ from the nearest land in the U.S.S.R. Foxes have travelled southward on ice floes as far as Anticosti Island in the Gulf of St. Lawrence (Seton 1925) and Cape Breton Island, Nova Scotia, and often reach northern Newfoundland (Cameron 1958). Record overland movements southward in North America have included ones to; $96 \mathrm{~km}$ north of McMurray, Alberta (Soper 1964); Carleton House, Saskatchewan (Richardson 1829); the south shore of East Shoal Lake, Manitoba (the present report); Township 10B, Sudbury district, Ontario (Peterson 1966); Lac Papineau, northeast of Montebello, Quebec (Macpherson 1968) - 500, $960,840,500$, and $700 \mathrm{~km}$ south of the breeding range, respectively. Even more surprising are southward penetrations of up to $2,000 \mathrm{~km}$ to Komsomolsk on the Amur River in the far eastern region of the U.S.S.R. (Belyaev 1959).

\section{MIGRATORY MOVEMENTS IN MANITOBA}

Several brief comments occur in the literature concerning fluctuations and movements of arctic foxes in northern Manitoba. Pennant (1784) stated that foxes ". . . are only migratory in Hudson's Bay once in four or five years." Hearne (1795) added: "The Arctic Foxes are in some years remarkably plentiful, but generally most so on the Barren-ground, near the sea coast ... They always come from the north along the coast, and generally make their appearance at Churchill [58 $\left.47^{\prime} \mathrm{N}, 94^{\circ} 11^{\prime} \mathrm{W}\right]$ about the middle of October, ... by frequent reinforcements from the northward, their numbers are so far increased as almost to exceed credibility.... When the Churchill River is frozen over near the mouth, the greatest part of the surviving White Foxes cross the river, and direct their course to the southward,..."

A large migration occurred in 1886 when 785 arctic foxes were trapped in the Lac du Brochet region in the forest-tundra of northwestern Manitoba (Seton 1925). Preble (1902) reported that: "The winter of 1900-1901 was remarkable for the great number of these animals which came southward, and for their wide dispersion in the interior [of Manitoba, formerly District of Keewatin]. Mr. 
J. K. MacDonald, of Norway House $\left[53^{\circ} 59^{\prime} \mathrm{N}, 97^{\circ} 50^{\prime} \mathrm{W}\right.$, wrote me that on account of the light fall of snow the foxes followed up the rivers from the Bay to the vicinity of the post."

Sutton (1962a) noted that: "This winter [1961-62] we have had some reports which indicate that for some reason these little arctic foxes are moving off the tundra and penetrating far south into the wooded areas." One came within the townsite of Thompson $\left(55^{\circ} 45^{\prime} \mathrm{N}, 97^{\circ} 52^{\prime} \mathrm{W}\right)$, and conservation officers reported animals as far south as Oxford House $\left(54^{\circ} 56^{\prime} \mathrm{N}, 95^{\circ} 16^{\prime} \mathrm{W}\right)$, Nelson House $\left(55^{\circ} 47^{\prime} \mathrm{N}, 98^{\circ} 51^{\prime} \mathrm{W}\right)$, South Indian Lake $\left(56^{\circ} 46^{\prime} \mathrm{N}, 98^{\circ} 57^{\prime} \mathrm{W}\right)$, Cross Lake $\left(54^{\circ} 37^{\prime} \mathrm{N}, 97^{\circ} 47^{\prime} \mathrm{W}\right)$ and Brochet $\left(57^{\circ} 53^{\prime} \mathrm{N}, 101^{\circ} 40^{\prime} \mathrm{W}\right)$. Others appeared at a mine and a dump at Lynn Lake $\left(56^{\circ} 51^{\prime} \mathrm{N}, 101^{\circ} 03^{\prime} \mathrm{W}\right)$ (Sutton $1962 \mathrm{~b}$ ).

In Fig. 2 are illustrated the breeding range of the arctic fox in Manitoba, records for 1974-75 migration, and earlier extra-limital records gathered from the literature, fur-harvest records, and museum specimens. Though foxes often penetrate the forest-tundra transition, few accurate records are available of their distribution within it, since the settlements there are widespread and trapline regions are large. About three dozen records now exist for the boreal forest, and the East Shoal Lake fox was taken well within the aspen-oak transition - only $30 \mathrm{~km}$ from the grassland region.

Manitoba fur-production data for the period 1919-75 reveal regular fluctuations in fox numbers, with peaks most commonly occurring at intervals of three years, but ranging from two to seven years (Table 1). The winter of 1924-25 was exceptionally productive, with 8400 foxes taken in Manitoba, while the minimal number of only 24 was reported in 1970-71. During the winters of 1961-62, 1964-65 and 1974-75, foxes appeared at southerly posts and settlements in Manitoba and Saskatchewan in greater numbers than usual, including many areas where they had rarely or never been reported before. The trapping of arctic foxes in many areas of the boreal forest is so unusual that many specimens are probably kept by trappers, and hence fur-production records do not give an accurate estimate of the number of foxes reaching this far south. The three recent major influxes of foxes were likely not just sporadic movements but migrations, involving large numbers of animals travelling hundreds of kilometres southward. During the 1974-75 migration, foxes were trapped in the vicinities of about 35 settlements (between one and 122 foxes at each) in Manitoba.

Several distribution records from the 1974-75 migration are extraordinary with respect to the great distances covered from the tundra breeding grounds. An arctic fox seen at North Shoal Lake in early winter was probably the same individual that was collected in mid-December at East Shoal Lake, $840 \mathrm{~km}$ from Hudson Bay (G. and D. Procter, Woodlands, Manitoba, personal communication). One was trapped in the foothills of the Porcupine Mountains $\left(52^{\circ} 30^{\prime} \mathrm{N}\right.$, $101^{\circ} 40^{\prime} \mathrm{W}$ ) in mid-December (about $650 \mathrm{~km}$ from Hudson Bay), and another along the Mukatawa River (Big Black River) $\left(53^{\circ} 10^{\prime} \mathrm{N}, 97^{\circ} 24^{\prime} \mathrm{W}\right)$ north of Poplar River Reserve on the east shore of Lake Winnipeg $(520 \mathrm{~km}$ from Hudson Bay). Of particular interest is a February 1975 record of an arctic fox trapped on Sandy Island $\left(52^{\circ} 58^{\prime}, 97^{\circ} 58^{\prime} \mathrm{W}\right), 34 \mathrm{~km}$ from the east shore of Lake Winnipeg, then frozen over. 
Many migrating foxes were trapped or observed along the rivers and lakes which drain from the south and west through the Precambrian Shield and Hudson Bay Lowlands to the coast. The snow cover on these watercourses is often shallower and more compacted (by the wind and the passage of snowmobiles) than in the forest, and the foxes appeared to take advantage of them, moving as a result with greater speed and over greater distances during migration.

The climate of Hudson Bay has caused the formation of a strip of coastal tundra extending southward to the latitude of York Factory $\left(57^{\circ} 00^{\prime} \mathrm{N}, 92^{\circ} 18^{\prime} \mathrm{W}\right)$ - well south of the Keewatin barren grounds - which probably serves to funnel transient foxes deep into the forests of Manitoba. Presuming that most of these foxes come from the region south and inland from Eskimo Point, District of Keewatin, N.W.T. (about $245 \mathrm{~km}$ northwest of Churchill), the present authors attempted to find whether microtine rodent fluctuations in this area might have influenced fox numbers and movements.

\section{FLUCTUATIONS OF ARCTIC FOX AND PREY SPECIES}

Shelford (1943) studied fluctuations of the collared lemming (Dicrostonyx torquatus) at Churchill from 1929 to 1941 , recording peaks and subsequent rapid declines in 1929-30, 1933-34, 1936-37, and 1940-41. These coincide with peaks in the numbers of foxes trapped in Manitoba during the winters of 1930-31 (2,512 foxes), 1933-34 (3,340), 1937-38 (578), and 1941-42 (1,139).

R. J. Brooks (personal communication), recorded the last peak of collared lemmings at Churchill in 1967 (up to 63 per hectare). The following summer the population dropped by 80 per cent and has remained at low levels, with in 1974 no animals at all recorded on an 82-hectare study plot. Lemmings were only rarely found in extensive trapping in the Churchill region during 1973 and 1974 (Wrigley 1974). Meadow voles (Microtus pennsylvanicus) and southern red-backed voles (Clethrionomys gapperi) were low to moderate in numbers during the nineteen seventies (Wrigley 1974; R. J. Brooks, personal communication).

At Seal River, $56 \mathrm{~km}$ northwest of Churchill, collared lemmings and meadow voles were common in 1973, with 12 and 37 per hectare, respectively, in sedgemoss tundra, and 61 meadow voles per hectare in beach-meadow (Wrigley 1974). R. J. Brooks, who worked at Eskimo Point from 1973 to 1975, found that the numbers of both the collared lemming and brown lemming (Lemmus sibiricus) reached a peak in 1973, but had fallen drastically by the summer of 1974, with fluctuations far more obvious in the case of the brown lemming. Their numbers continued to be low through 1975 , and even meadow voles were uncommon.

Following the lemming peak at Churchill in the summer of 1967, and the subsequent decline during the next winter, 727 arctic foxes were trapped in Manitoba during the 1967-68 season (Table 1) - a relatively low peak in the fox's approximately three-year cycle. A scarcity of lemming prey from 1968 until 1973 was associated with poor fox yields in Manitoba (ranging from 24 to 160 animals), and a decrease in fur production in the Eskimo Point region $(983$ to 1,697). An abundance of lemmings in 1973, along the west coast of Hudson Bay north 
TABLE 1. Annual harvest of arctic fox in Manitoba from 1919 to 1975

\begin{tabular}{|c|c|c|c|}
\hline Fur Year & Pelts Taken & Fur Year & Pelts Taken \\
\hline 1919-20 & $1457^{*}$ & $1947-48$ & 91 \\
\hline 1920-21 & 88 & $1948-49$ & 55 \\
\hline $1921-22$ & 2673 & $1949-50$ & 99 \\
\hline $1922-23$ & $3202^{*}$ & $1950-51$ & 287 \\
\hline 1923-24 & 1083 & 1951-52 & 431 \\
\hline $1924-25$ & $8400^{*}$ & $1952-53$ & $1324^{*}$ \\
\hline $1925-26$ & 865 & 1953-54 & 669 \\
\hline $1926-27$ & $4572^{*}$ & $1954-55$ & 324 \\
\hline $1927-28$ & 659 & $1955-56$ & $632^{*}$ \\
\hline $1928-29$ & $930^{*}$ & $1956-57$ & 115 \\
\hline $1929-30$ & 792 & $1957-58$ & 732 \\
\hline $1930-31$ & $2512^{*}$ & $1958-59$ & $1126^{*}$ \\
\hline $1931-32$ & 1623 & $1959-60$ & 190 \\
\hline $1932-33$ & 1181 & $1960-61$ & 517 \\
\hline 1933-34 & $3340^{*}$ & $1961-62$ & $2843^{*}$ \\
\hline $1934-35$ & 884 & $1962-63$ & 109 \\
\hline $1935-36$ & 238 & $1963-64$ & 422 \\
\hline $1936-37$ & 233 & $1964-65$ & $1766^{*}$ \\
\hline $1937-38$ & $578^{*}$ & $1965-66$ & 148 \\
\hline $1938-39$ & 396 & $1966-67$ & 378 \\
\hline $1939-40$ & 251 & $1967-68$ & $739^{*}$ \\
\hline $1940-41$ & 584 & $1968-69$ & 137 \\
\hline $1941-42$ & $1139^{*}$ & $1969-70$ & 32 \\
\hline $1942-43$ & 484 & $1970-71$ & 24 \\
\hline $1943-44$ & 372 & $1971-72$ & 38 \\
\hline $1944-45$ & 315 & $1972-73$ & 160 \\
\hline $1945-46$ & 303 & $1973-74$ & 65 \\
\hline $1946-47$ & $1472^{*}$ & $1974-75$ & $630^{*}$ \\
\hline
\end{tabular}

*Fluctuation peaks

of Seal River (Wrigley 1974), was likely a major factor in the exceptional increase in fox numbers - 5,274 were trapped in the vicinity of Eskimo Point in the winter of 1973-74. The lemming decline by the summer of 1974 was the probable cause of the 1974-75 migration of foxes into southern Manitoba (630 taken in Manitoba, 3,211 at Eskimo Point). 


\section{DISCUSSION}

The correlation of lemming and arctic fox fluctuations was first described by Gmelin (1760). Since then, numerous studies have served to show that peaks in the three-to-four-year cycle of lemmings result in a rapid build-up of fox populations through larger litter size and increased survival of whelps, while the subsequent lemming decline causes widespread starvation and mass migration of foxes (Kirpichnikov 1937; Chitty 1950; Tchirkova 1951; Macpherson 1969).

During a migration year (occurring usually every three to five years), foxes, particularly adult males, commence moving in random directions in September. By October or November, their movement develops into a well-marked wave in a certain direction. Those individuals heading out onto the polar ice feed on a variety of marine life, but mainly on seal carrion left by polar bears, though, apparently most of them perish from starvation (Bannikov 1970). Foxes penetrating the forest-tundra and forests to the south consume lemmings, other microtine rodents, ptarmigan and hares (Chesemore 1968b), while others follow caribou or reindeer herds, attacking the weaker young (Porsild 1945) or feeding on the remains of wolf kills (Manning 1943). During the 1974-75 migration in Manitoba, foxes with information on date of capture were almost all taken between November and January (with one recorded in February), and predominantly in December. Thus most foxes would have migrated into the forest-tundra zone during November and early December. This is the period when the Kaminuriak herd of barren-ground caribou (about 63,000 animals) move from their calving grounds south of Baker Lake, District of Keewatin, on their annual migration to winter grounds in the northwestern corner of Manitoba and in adjacent Saskatchewan. Parker (1972) estimated the annual mortality rate from predation to be 10.1 per cent -5.3 per cent from native kill, and 4.8 per cent from 550 wolves (13 caribou per wolf per year). Thus many caribou carcasses would be available to arctic foxes migrating from the barrens to the forest zone.

In the U.S.S.R., Dementyeff (1955) found that direction of migration is determined by ease of passage through the terrain (made possible by, for example, snow cover or freeze-up of rivers and lakes) and the prevailing winds, rather than by availability of food. Foxes do not remain long at a feeding site, but push on in the chosen direction, travelling usually singly for days and nights without stopping. It seems as though, once migrating, the foxes cannot settle at any place along the route, in spite of the availability of food there. They eat almost any food item, and consequently are easily taken at baited traps. In bad weather they burrow into snow banks.

Depending on the terrain and the intensity of their migration, the animals move in a wide front or in a narrow corridor, sometimes creating beaten paths (Bannikov 1970). As a wave passes over a region, local foxes may be drawn into the stream by the invaders. If food resources are sufficient, the wave moves slowly, terminates early, and does not spread very far (Shilyaeva 1967). In some years a number of waves, or "yuros" may pass through a given area. Dementyeff (1955) noted 


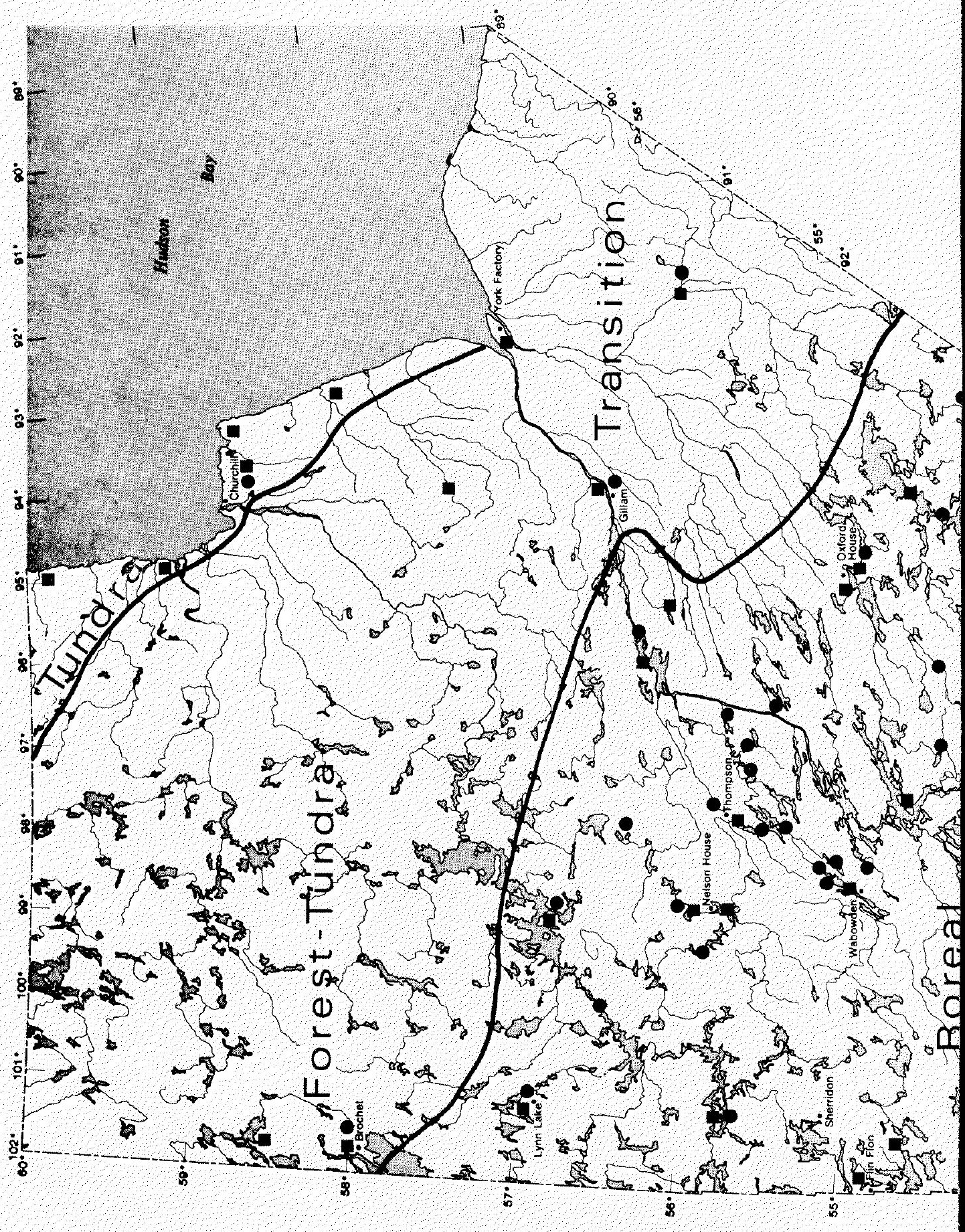




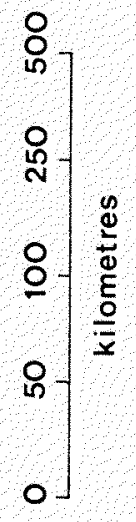

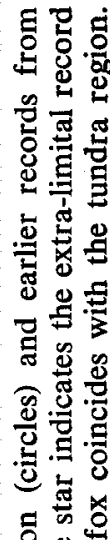

氜 अude

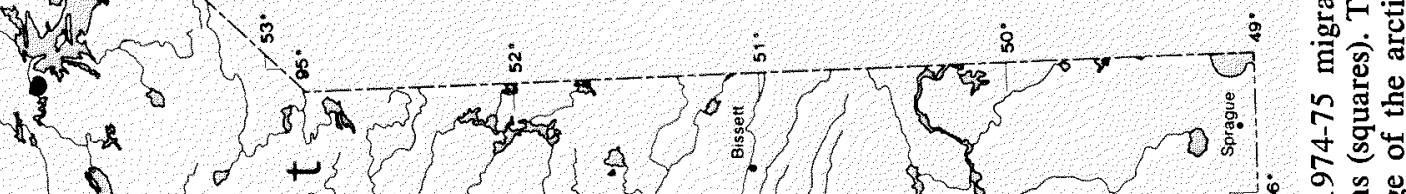

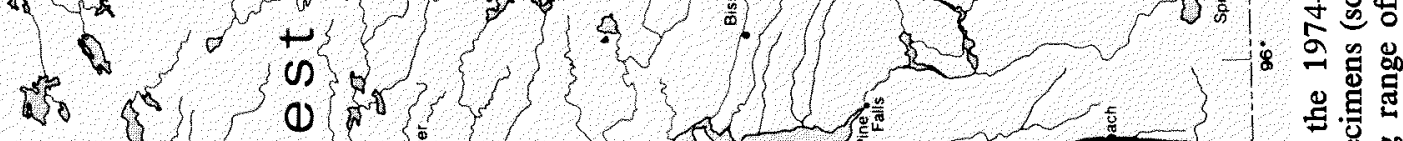

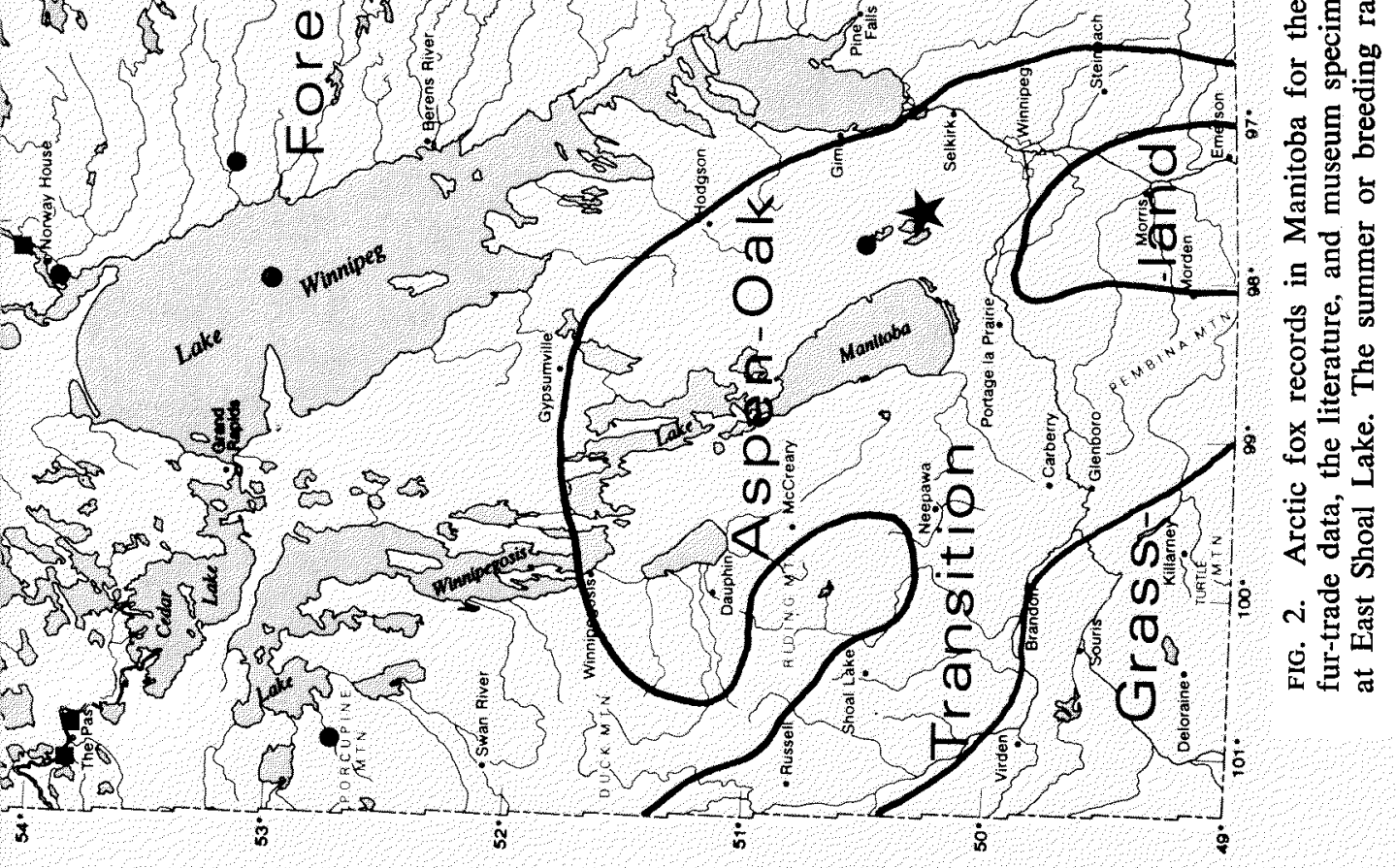


that the first wave, which continued until the end of November, consisted of foxes in good physical condition. A second wave, of weaker foxes, occurred in late December; and a third in late January in which the animals were thin. From mid-February to the end of March (when the breeding season starts) there was a slow movement back to the tundra. Kirpichnikov (1937) concluded that the passage from south to north is not of the same mass character, nor concentrated during particular periods, and hence is less noticeable.

Formerly there was little information to suggest that arctic foxes returned to their summer range after travelling many hundreds of kilometres into unfamiliar territory (Hearne 1795; Seton 1925; Formozov 1969). The narrow paws and short legs, which carry the animal lightly over the thin and wind-compacted snow cover of the tundra, bog down in the snow of the taiga which is often deep and fluffy. And although these foxes are experts at locating food at great distances or under deep snow cover (Braestrup 1941), many are in poor condition by late winter. Most of them die of starvation, disease - particularly rabies which may affect up to 75 per cent of the population during the migratory period (Syuzyumova 1967) - or are trapped (Bannikov 1970). Many others likely fall prey to larger predators. The female arctic fox taken at East Shoal Lake had a wound on its side, and the collectors surmised that it had been attacked by a red fox or coyote.

Without a resort to large-scale tagging experiments, the percentage of migrants successfully completing the round trip must remain unknown. The species is not known to breed, or survive for extended periods, in the forest zone, though Northcott (1975) reported a wild arctic fox surviving on Newfoundland for 11 months (April to March) after rafting to the island on an ice floe.

There is some evidence that arctic foxes navigate a particular course during migration. The fact that the native "blue" fox population of northwestern Greenland is subject to periodic invasions by white migrants from Canada, after which it quickly regains its separate existence, may indicate a return of the white foxes (Braestrup 1941). Furthermore, the presence of distinct populations of "Obdorsk" and "Pechora" varieties of foxes in the European part of the U.S.S.R. likewise suggests a return of migrants (Shilyaeva 1967). An unusual example of homing behaviour was noted by Macpherson (1968): a captive fox from Aberdeen Lake, District of Keewatin, escaped near Ottawa, Ontario, and two years later was trapped on the Belcher Islands of Hudson Bay, 1,120 km to the northwest, while apparently heading homeward.

Migrations of arctic fox in North America either occur on a smaller magnitude than in Eurasia, or perhaps have just not been recorded as well. Chesemore (1968a) recognized many instances of sporadic movements of individual foxes southward along the coast and through inland regions of Alaska, as well as regular seasonal movements, but found no evidence of migrations in the literature or from trappers. The present paper documents the existence of arctic fox migrations in Manitoba and correlates fox abundance and movements with lemming fluctuations. Yet to be substantiated is whether the many characteristics of arctic fox movements in the U.S.S.R. apply to North American populations. 


\section{ACKNOWLEDGEMENTS}

We thank R. R. P. Stardom (Manitoba Department of Renewable Resources and Transportation Services), L. R. McIntosh (Hudson's Bay Company) and J. Gould (Northwest Territories Fish and Wildlife Service) for supplying fur-harvest records of arctic fox; R. R. Riewe (University of Manitoba) for making available literature on arctic fox migrations; and A. H. Macpherson (Environment Canada), J. T. Strong (Northwest Territories Fish and Wildlife Service) and L. S. Underwood (University of Alaska) for contributing information on long-range movements. R. J. Brooks (University of Guelph) kindly supplied data on rodent numbers along the western coast of Hudson Bay. R. Stardom, M. Shoesmith, and R. R. Riewe reviewed the manuscript. Finally we gratefully acknowledge the assistance of many Manitoba wildlife biologists and conservation officers whose fox reports formed the basis of this paper.

\section{REFERENCES}

BANNIKov, A. G. 1970. Arctic foX in the U.S.S.R.: biological premises of productivity. In: Fuller, W. A. and Kevan, P. G. (eds.), Productivity and Conservation in Northern Circumpolar Lands, Morges, Switzerland: IUCN (New Series Publication, no. 16), pp. 121-30.

BELYaEv, v. 1959. Belyi pesets pod Komsomol'skom (Arctic fox in the Komsomolsk region). Okhota i okhotich'e khozyaistvo, no. 4 (Moscow).

BRAESTRUP, F. W. 1941. A study on the arctic fox in Greenland. Meddelelser om Gronland, 131 (4): 1-101.

Cameron, A. W. 1958. Mammals of the islands in the Gulf of St. Lawrence. National Museums of Canada Bulletin 154: 1-165.

CHESEMORE, D. L. 1968a. Distribution and movements of white foxes in northern and western Alaska. Canadian Journal of Zoology 46: 849-54.

1968b. Notes on the food habits of arctic foxes in northern Alaska. Canadian Journal of Zoology 46: 1127-30.

CHITTY, H. 1950. Canadian arctic wild life enquiry, 1943-49: with a summary of results since 1933. Journal of Animal Ecology 19: 180-193.

DEMENTYEFF, N. I. 1955. Biology of the arctic fox in the Bolshezemelskaya Tundra. Russian Game Report, vol 3 (translation). Ottawa: Queen's Printer, 1958 pp. 166-81.

elton, c. 1942. Voles, Mice and Lemmings; Problems in Population Dynamics. Oxford: Clarendon Press.

FORMOZOV, A. N. 1969. Snow Cover as an Integral Factor of the Environment and its Importance in the Ecology of Mammals and Birds. Edmonton, Alberta: Boreal Institute, University of Alberta (Occasional Paper no. 1).

OMELIN, 1. G 1760. Animalium quorundam quadrupedum descriptio. Novyi Kommentarii Acad. Scient. Imp. Petrop., 5: 338-72.

HEARNE, S. 1795. A Journey from Prince of Wales' Fort in Hudson's Bay to the Northern Ocean. London: Strahan and Cadell. pp. 363-4.

KIRPICHNIKOV, A. A. 1937. On the Biology of the Arctic Fox on the Southwest Coast of Taimyr (from material collected during a winter - 1933-34 - spent on Dickson Island). Oxford: Bureau of Animal Populations, Oxford University (Translation 101, F 1051, A: 1-16).

LaVrov, N. P. 1932. The arctic fox. In: Zhitkov, B. M. (ed.), Fur-bearing Animals of the U.S.S.R. Oxford: Bureau of Animal Populations, Oxford University (Translation 18, F1079, A1-92).

MACPHERSON, A. H. 1968. Apparent recovery of translocated arctic fox. Canadian FieldNaturalist, 82: 287-89.

1969. The dynamics of Canadian arctic fox populations. Canadian Wildlife Service, Report Series no. 8.

MANNING, T. H. 1943. Notes on the mammals of south and central west Baffin Island. Journal of Mammalogy, 24: 47-59.

MCEWEN, E. H. 1951. A literature review of arctic foxes. (Unpublished M.A. thesis, University of Toronto).

NORTHCOTT, T. 1975. Long-distance movement of an arctic fox in Newfoundland. Canadian Field-Naturalist, 89: 464-5. 
PARKER, G. R. 1972. Biology of the Kaminuriak population of barren-ground caribou. Canadian Wildlife Service, Report Series no. 20, part 1.

PENNANT, T. 1784. Arctic Zoology, Vol. 1: Quadrupeds. London: Henry Hughs.

PETERSON, R. L. 1966. The Mammals of Eastern Canada. Toronto: Oxford University Press. PORSILD, A. E. 1945. Mammals of the Mackenzie Delta. Canadian Field-Naturalist, 59: 4-22. PREBLE, E. A. 1902. A biological investigation of the Hudson Bay region. North American Fauna, 22: 1-140.

RICHARDSON, J. 1829. Fauna Boreali-Americana, Part 1. London: John Murray.

SETON, E. T. 1925. Lives of Game Animals, Volume I, Part II. Boston: Charles T. Branford. pp. 423-65.

SHELFORD, V. E. 1943. The abundance of the collared lemming (Dicrostonyx groenlandicus (T.R.) var. richardsoni Mer.) in the Churchill area, 1929 to 1940. Ecology, 24: 472-84.

ShILYAEVA, L. M. 1967. Studying the migration of the arctic fox. Problems of the North, Volume II (translation). Ottawa: National Research Council of Canada. pp. 103-12. SOPER, J. D. 1964. The Mammals of Alberta. Edmonton: Hambly Press.

sutTon, R. W. 1962a. The mischievous arctic fox. Winnipeg Free Press, Wildlife Notebook, 6 January, 1962.

February 1962.

1962b. Foxes letters and birds. Winnipeg Free Press, Wildlife Notebook, 24

syUZYUMova, L. M. 1967. Epizootiology of rabies among arctic foxes on the Yamal Peninsula. Problems of the North, Vol. 2 (translation). Ottawa: National Research Council of Canada.

TCHIRKova, A. F. 1951. A preliminary method of forecasting changes in numbers of arctic foxes. Russian Game Report, Vol. 3 (translation). Ottawa: Queen's Printer.

USPENSKII, S. M. 1956. Pozvonochnye zhivothye Tsentral'noi Arktiki (Vertebrates of the central Arctic). Priroda, no. 8 (Moscow).

WRIGLEY, R. E. 1974. Ecological notes on animals of the Churchill region of Hudson Bay. Arctic, 27: 201-14. 